\title{
Numerical Evaluation of Tunnel Portal Slope Stability at Bagong Dam Site, East Java, Indonesia
}

\author{
Irien Akinina Fatkhiandari, I Gde Budi Indrawan*, and Dwikorita Karnawati \\ Department of Geological Engineering, Faculty of Engineering, Universitas Gadjah Mada, Yogyakarta, Indonesia
}

\begin{abstract}
Geometries of excavated tunnel portal slopes at Bagong Dam site was initially designed without taking into account the earthquake load. The excavated slope designs also assumed that the rocks comprising the slopes were homogenous. The purpose of this research was to evaluate the stability of the excavated tunnel inlet and outlet slopes at the Bagong Dam site under static and earthquake loads using the finite element method. The stability of the natural slopes was also analyzed for comparison. The numerical static and pseudostatic analyses of slope stability were carried out using RS2 software (Rocscience, Inc.). Input data used in the numerical analyses were obtained from engineering geological mapping, rock core analyses, and laboratory tests. The seismic coefficient applied in the pseudo-static slope stability analyses was determined following guideline described in Indonesian National Standard. The engineering geological mapping and evaluation of rock cores indicated that the inlet tunnel slope consisted of four types of materials, namely residual soil, poor quality of volcanic breccia, very poor quality of volcanic breccia, and good quality of volcanic breccia. The outlet portal slope consisted of six types of materials, namely residual soil, very poor quality of limestone, poor quality of limestone, very poor quality of volcanic breccia, poor quality breccia, and good quality breccia. Based on the secondary elastic wave velocity $(\mathrm{Vs})$ values, the rock masses in the research area were classified as hard rock (SA). Seismic analyses based on the earthquake hazard source map with a $10 \%$ probability of exceedance in 50 years provided by the National Earthquake Center (2017) indicated that the PGA and the corresponding amplification factor FPGA in the research area were 0.3 and 0.8 , respectively. The calculated seismic coefficient for the pseudostatic slope stability analyses was 0.12 . The numerical analysis results showed that, in general, earthquake load reduced critical Strength Reduction Factor (SRF) values of the slopes. However, the natural and excavated tunnel portal slopes were relatively stable under static and earthquake loads. The natural slope at the tunnel inlet with a $40^{\circ}$ inclination had a critical SRF value of 4.0, while that of at the tunnel outlet with a $51^{\circ}$ inclination had a critical SRF value of 2.6. Under static load, the excavated slopes at the tunnel inlet and outlet having a $45^{\circ}$ inclination had critical SRF values of 2.4 and 5.0, respectively. Under earthquake load, the excavated slopes at the tunnel inlet and outlet had critical SRF values of 2.3 and 3.5, respectively.
\end{abstract}

Keywords: Bagong dam · Finite element method · GSI · RS2 · Slope stability.

\footnotetext{
${ }^{*}$ Corresponding author: I G. B. InDRAWAN, Department of Geological Engineering, Universitas Gadjah Mada. Jl. Grafika 2 Yogyakarta, Indonesia. E-mail: igbindrawan@ugm.ac.id
}

\section{INTRODUCTION}

The Bagong Dam site is located at Sumurup and Sengon Villages, Bendungan District, Trenggalek Regency, East Java Province (Figure 1). For the construction of the earth-fill dam, the river water was planned to be diverted using a 
diversion tunnel. Geometries of the inlet and outlet tunnel portal slopes were designed by BBWS Brantas (2017) using a numerical software Plaxis developed by Bentley Systems, Inc. However, earthquake load was not considered into the slope designs. In addition, the rocks comprising the slopes were assumed to be homogenous, and the shear strength parameters for the slope stability analyses were obtained from laboratory direct shear strength tests. As located in an active seismic region, the stability of the tunnel portal slopes may be affected by earthquakes. As discontinuities tend to reduce rock mass strength, ignoring rock mass quality controlled by rock fractures may lead to overestimated slope factor of safety. Therefore, stability evaluation of the designed inlet and portal slopes by taking into account the earthquake load and rock fracturing degree is necessary.

The finite element method has been increasingly used in slope stability analyses (Hammah et al., 2004). Excellent reviews of finite element analyses of slope stability are provided in numerous textbooks (e.g., Duncan et al., 2014; Wyllie, 2018). One of the advantages of the finite element method over the traditional limit equilibrium method is that no assumption needs to be made in advance about the shape or location of the failure surface (e.g., Griffith and Lane, 1999; Rocscience Inc., 2001).

This paper presents results of engineering geology study carried out to evaluate the stability of designed tunnel portal slopes at The Bagong Dam site under static and earthquake loads using the finite element method. Results of the engineering geological mapping and rock core evaluations are presented, and results of static and pseudostatic slope stability analyses are highlighted.

\section{Geological Setting}

The Regional Geological Map of Madiun Sheet prepared by Hartono et al. (1992) shows that the Bagong Dam site and the surrounding consist of the Mandalika and Wonosari Formations (Figure 2). The Mandalika Formation was estimated to form in Oligocene to Early Miocene, while the Wonosari Formation was estimated to form in Early to Late Miocene. Based on surface geological mapping and evaluation of drill cores, Fatkhiandari (2020) indicated that two main types of lithologies, namely volcanic breccia and limestone, existed in the Bagong Dam site were likely members of the Mandalika and Wonosari Formations, respectively. In addition, faults and joints observed in the Bagong Dam site and the surrounding had a consistent orientation to the regional Meratus structural pattern (NE-SW), as described by Pulunggono dan Martodjodjo (1994).

\section{METHOD}

Engineering geological mapping around the tunnel portals, evaluation of rock cores at four boreholes drilled by BBWS Brantas (2014) near the inlet and outlet tunnel portals (Figure 1), and laboratory testing of soil and rock samples were carried out to obtain data of rock mass layers and the engineering properties. Rock mass quality was determined by the Geological Strength Index (GSI) of the rock cores following equation proposed by Hoek et al. (2013) as follows:

$$
G S I=1.4 J_{\text {cond }}+\frac{R Q D}{2}
$$

where $J_{\text {cond }}=$ joint conditions of rock cores as described in Bieniawski (1989); $R Q D=$ rock quality designation.

The pseudostatic slope stability analyses were carried out to estimate the stability of the tunnel portal slopes under an earthquake load. Following procedures described in SNI 8460 (BSN, 2017), the seismic coefficient used in pseudostatic slope stability analyses were calculated as 0.5 of the peak ground acceleration (PGA) determined by considering the site class and amplification factor $\left(F_{\mathrm{PGA}}\right)$. In addition, the SNI 8460 (BSN, 2017) adopts ground motions with a $10 \%$ probability of exceedance in 50 years (corresponding approximately to a 500-year return period) for seismic slope design. The peak ground acceleration at particular sites can be obtained from earthquake hazard source maps produced by the National Earthquake Center (2017).

The static and pseudostatic slope stability analyses were carried out using a finite element based RS2 software developed by Rocscience, Inc. The input parameters in the slope stability analyses are shown in Table 1. Figure 3 shows the geometries of the natural slopes with the 


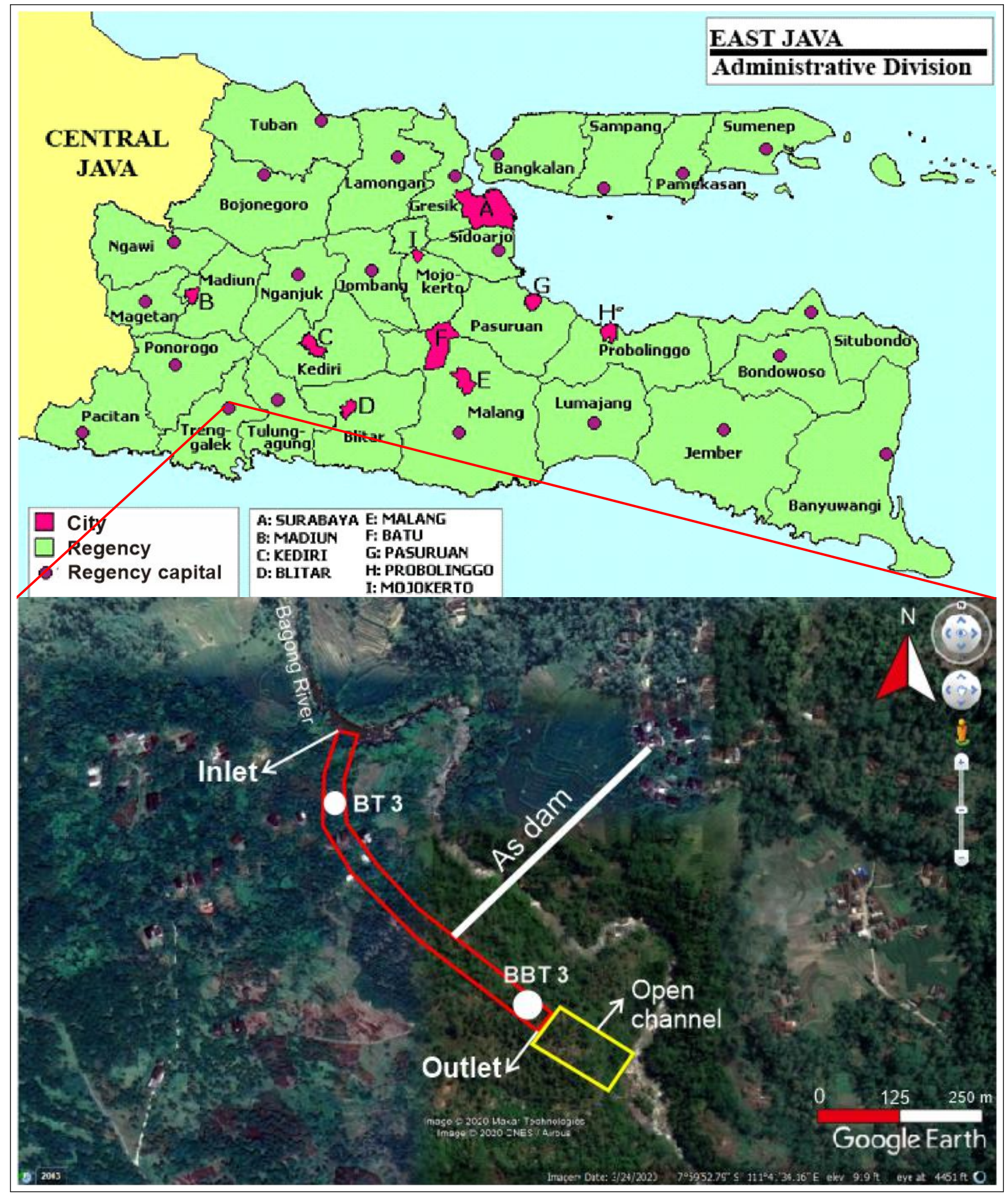

FIGURE 1. Research area at the Bagong Dam site. 


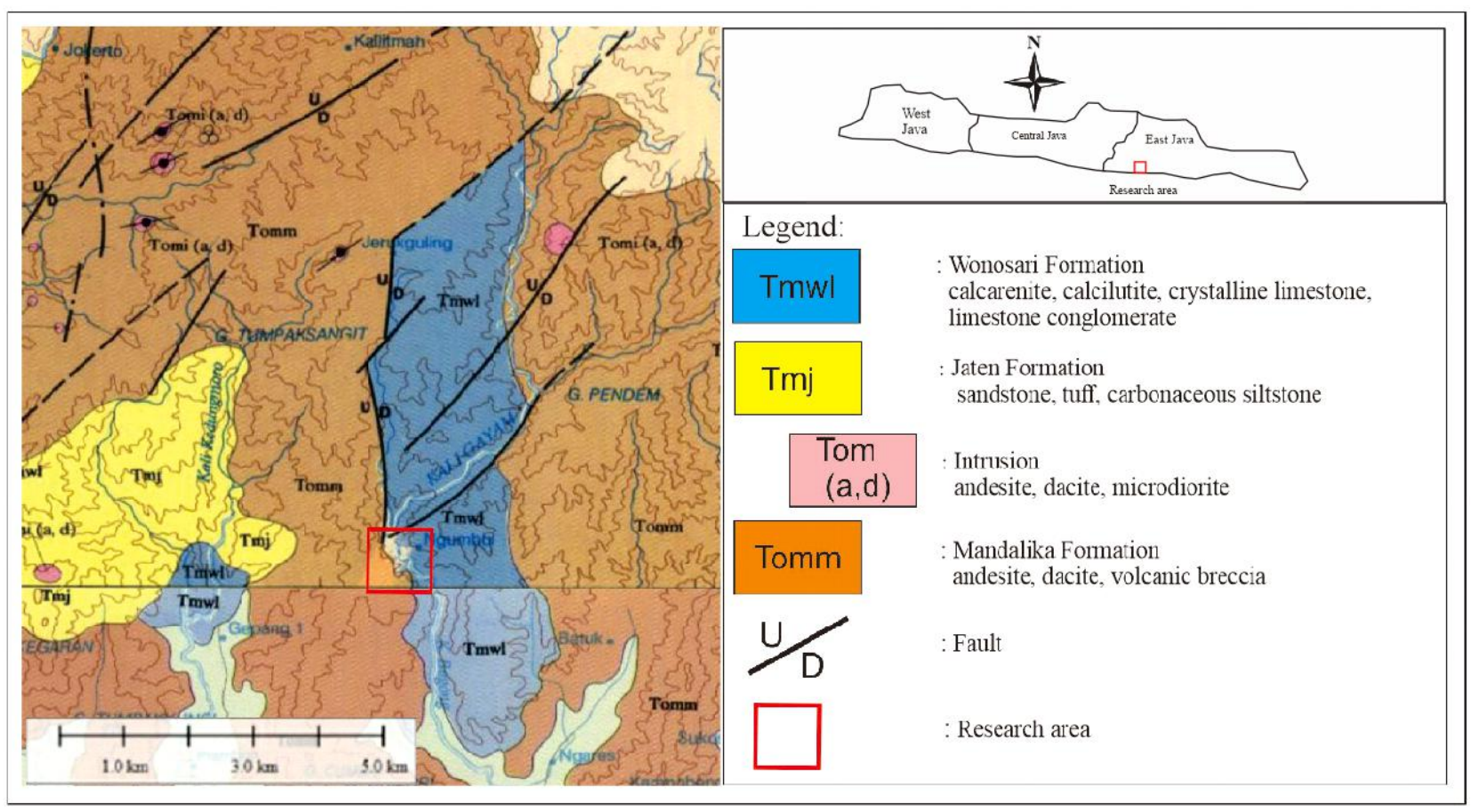

FIGURE 2. Regional geological map of the Madiun sheet (Hartono et al.,1992).

rock masses applied in the slope stability analyses. The natural slope at the tunnel inlet had a $40^{\circ}$ inclination, while that of at the tunnel outlet had a $51^{\circ}$ inclination. The groundwater levels in both slopes were inferred from drilling data. Following the best practice of excavated slope design, the excavated slopes at the tunnel inlet and outlet were designed to have a 1:1 slope ratio (or $45^{\circ}$ inclination). The SNI 8460 (BSN, 2017) required a minimum factor of safety values of 1.5 and 1.1 for permanent slopes under static and earthquake loads, respectively. In the numerical finite element analyses, the factor of safety values was represented by critical Strength Reduction Factor (SRF) values.

\section{Results AND Discussion}

\subsection{Rock mass types and properties}

Types and qualities of the rock masses comprising the inlet and outlet tunnel portal slopes are shown in Table 2. Those characteristics of the rock masses were determined from the engineering geological mapping and evaluation of the rock cores at Borehole BT3 and BBT 3 (Table 1). The inlet tunnel slope consisted of four types of materials, namely residual soil, poor quality of volcanic breccia, very poor quality of volcanic breccia, and good quality of volcanic breccia. Meanwhile, the outlet portal slope con- sisted of six types of materials, namely residual soil, very poor quality of limestone, poor quality of limestone, very poor quality of volcanic breccia, poor quality breccia, and good quality breccia. Typical cores of rock masses comprising the slopes are shown in Figure 4. The material properties from the laboratory tests (Table 4) then used as input parameters in the slope stability analyses. Intact rock constant (mi) of each rock mass quality was estimated based on the range of mi value for each rock type provided in the RS2 database by considering the weathering degree of the intact rock. Disturbance factor $(D)$ values were all set into zero by assuming that the excavation processes caused minimum disturbance to the surrounding rock masses.

\subsection{Earthquake load}

Measurement data of the previous study (BBWS Brantas, 2014) indicated that the research area had more than $1500 \mathrm{~m} / \mathrm{s}$ secondary elastic wave velocity $\left(V_{s}\right)$ values. Therefore, the rock masses are classified as a hard rock (SA) class. The earthquake hazard source map with a $10 \%$ probability of exceedance in 50 years provided by the National Earthquake Center (2017) indicated that the PGA and the corresponding amplification factor FPGA in 
TABLE 1. Input parameters for slope stability analyses.

\begin{tabular}{ll}
\hline Analysis type & Plane strain \\
\hline Stress analysis & $\begin{array}{l}\text { Tensile failure reduce shear strength; } \\
\text { Joint tension reduce joint stiffness } \\
\text { Effective stress analyses (static load); total stress analyses (earthquake load) }\end{array}$ \\
\hline Mesh & Graded, 3-noded triangle \\
\hline Field stress & Gravity, actual ground surface \\
\hline Displacement & Top: Free \\
& $\begin{array}{l}\text { Side: Restrain XY } \\
\text { Bottom: Restrain XY }\end{array}$ \\
\hline Material properties & Initial element loading: Field stress \& body force \\
& Failure criteria: Mohr-Coulomb (soil); Generalized Hoek-Brown (rock) \\
& Material type: Plastic \\
\hline
\end{tabular}

TABLE 2. Rock masses at borehole BT3 (inlet slope).

\begin{tabular}{cllcccc}
\hline Depth $(\mathrm{m})$ & Material & Weathering degree & $J_{\text {cond }}$ & RQD & GSI & Rock mass quality \\
\hline $0-3$ & Residual soil & $\begin{array}{l}\text { Completely } \\
\text { weathered }\end{array}$ & 0 & 0 & - & - \\
\hline $3.5-30$ & Volcanic breccia & $\begin{array}{l}\text { Moderately } \\
\text { weathered }\end{array}$ & 15 & 7 & 26 & $\begin{array}{l}\text { Poor quality of volcanic } \\
\text { breccia }\end{array}$ \\
\hline $30-40$ & Volcanic breccia & Highly weathered & 10 & 0 & 15 & $\begin{array}{l}\text { Very poor quality of } \\
\text { volcanic breccia }\end{array}$ \\
\hline $40-70$ & Volcanic breccia & Slightly weathered & 25 & 44 & 59.5 & $\begin{array}{l}\text { Good quality of } \\
\text { volcanic breccia }\end{array}$ \\
\hline
\end{tabular}

TABLE 3. Rock masses at borehole BBT3 (outlet slope).

\begin{tabular}{cllcccc}
\hline Depth $(\mathrm{m})$ & Material & Weathering degree & $J_{\text {cond }}$ & $R Q D$ & GSI & Rock mass quality \\
\hline $0-3$ & Residual soil & $\begin{array}{l}\text { Completely } \\
\text { weathered }\end{array}$ & 0 & 0 & - & - \\
\hline $3-17$ & Limestone & Highly weathered & 10 & 0 & 15 & $\begin{array}{l}\text { Very poor quality of } \\
\text { limestone }\end{array}$ \\
\hline 17-20.8 & Volcanic breccia & $\begin{array}{l}\text { Moderately } \\
\text { weathered }\end{array}$ & 15 & 7 & 26 & $\begin{array}{l}\text { Moderate quality of } \\
\text { volcanic breccia }\end{array}$ \\
\hline $20.8-35.2$ & Limestone & $\begin{array}{l}\text { Very highly } \\
\text { weathered }\end{array}$ & 10 & 6 & 18 & $\begin{array}{l}\text { Very poor quality of } \\
\text { limestone }\end{array}$ \\
\hline $35.2-50$ & Volcanic breccia & Slightly weathered & 25 & 70 & 72.5 & $\begin{array}{l}\text { Good quality of } \\
\text { volcanic breccia }\end{array}$ \\
\hline
\end{tabular}


Numerical Evaluation of Tunnel Portal Slope Stability at Bagong Dam Site
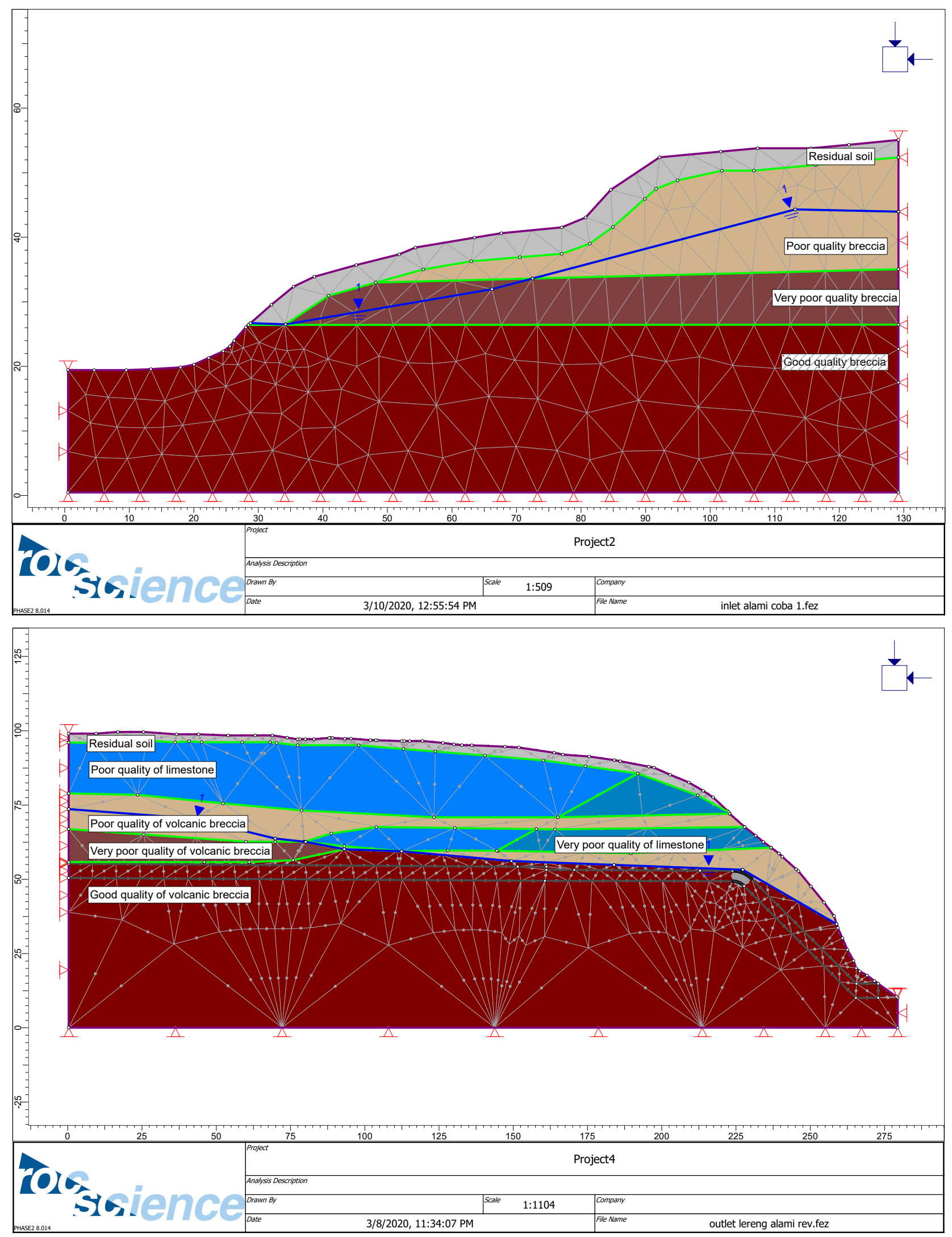

FIGURE 3. Geometries of natural slopes: (a) inlet; (b) outlet. 

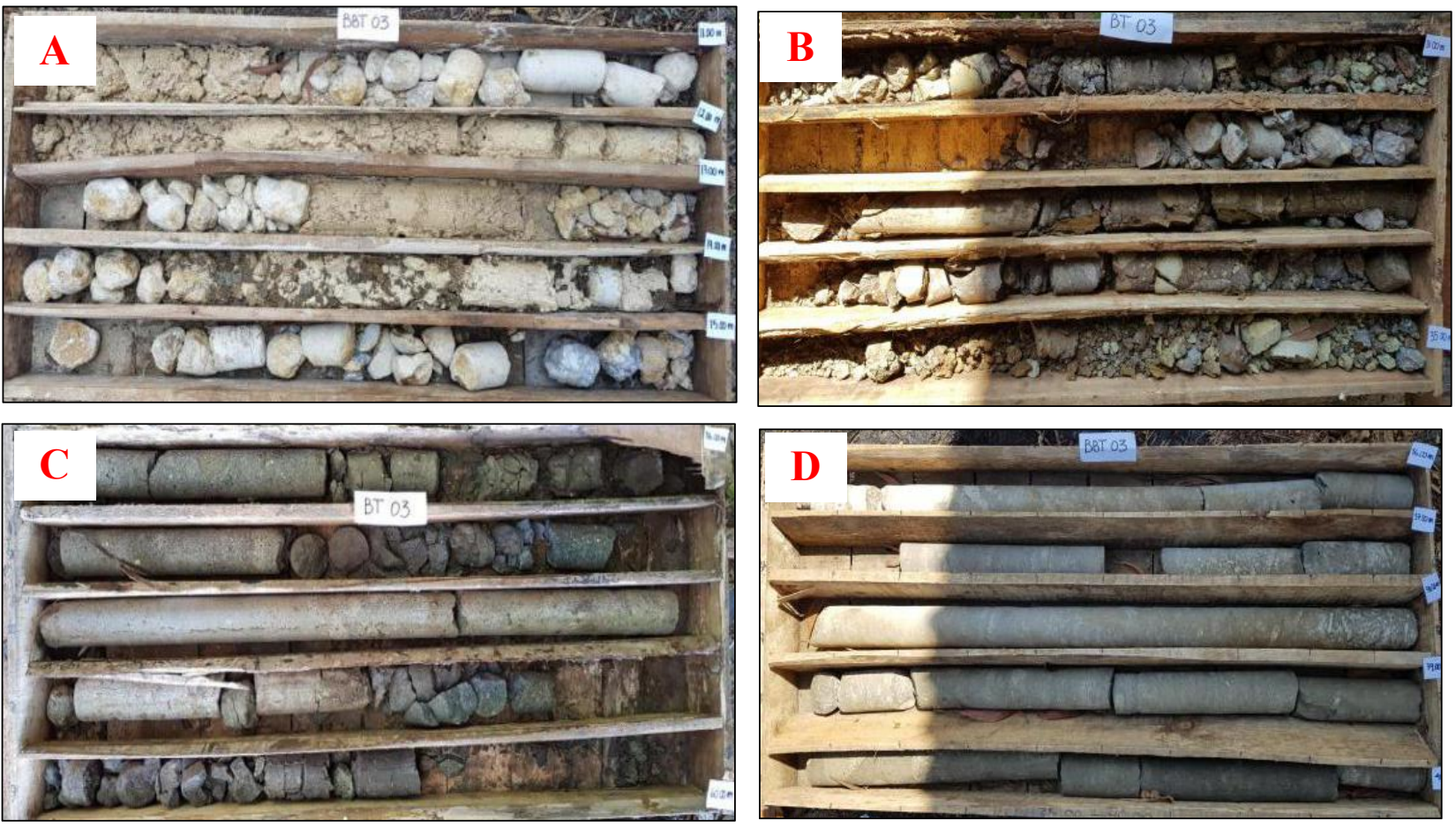

FIGURE 4. Photographs of rock cores: (A) very poor quality of limestone; (B) very poor quality of volcanic breccia; (C) moderate quality of volcanic breccia; (D) good quality of volcanic breccia.

the research area were 0.3 and 0.8 , respectively. The calculated seismic coefficient for the pseudostatic slope stability analyses was, therefore, 0.12 .

\subsection{Portal slope stability}

Contours of maximum shear strains resulted from the slope stability analyses for the natural and excavated slopes under static and earthquake loads are shown in Figure 5 to Figure 8. At the same time, the critical SRF values are summarized in Table 5. In general, the natural and designed excavated slopes met the stability requirements specified in SNI 8460 (BSN, 2017), where the slopes under static and earthquake loads had critical SRF (or factor safety) of more than 1.5 and 1.1, respectively. Figure 6 and Figure 8 show that maximum shear strains developed at the toes of the inlet and outlet excavated slopes above the tunnel portal. The maximum shear strain values were relatively insignificant (i.e., less than $5 \%$ ), and the critical SRF values were relatively high.

The simulation results imply that the earthquake load reduces the critical SRF values of all the slopes. Under the static load, the critical SRF value of the inlet slope decreased as the slope inclination increased due to excavation (i.e., $40^{\circ}$ for natural inlet slope and $45^{\circ}$ for excavated inlet slope). Meanwhile, the critical SRF value of the outlet slope increased as the slope inclination reduced due to excavation (i.e., $51^{\circ}$ for natural outlet slope and $45^{\circ}$ for excavated outlet slope). The trends of decreased and increased critical SRF values of the inlet and outlet slopes, respectively, under static load, were consistent with those under earthquake load (Table 5).

\section{CONCLUSIONS}

The engineering geological mapping and evaluation of rock cores indicated that the inlet tunnel slope consisted of four types of materials, namely residual soil, poor quality of volcanic breccia, very poor quality of volcanic breccia, and good quality of volcanic breccia. The outlet portal slope consisted of six types of materials, namely residual soil, very poor quality of limestone, poor quality of limestone, very poor quality of volcanic breccia, poor quality breccia, and good quality breccia. Based on the secondary elastic wave velocity $\left(V_{s}\right)$ values, the rock masses in the research area were classified as hard rock (SA). Seismic analyses based on the earthquake hazard source map with a $10 \%$ probability of exceedance in 50 years pro- 
Numerical Evaluation of Tunnel Portal Slope Stability at Bagong Dam Site
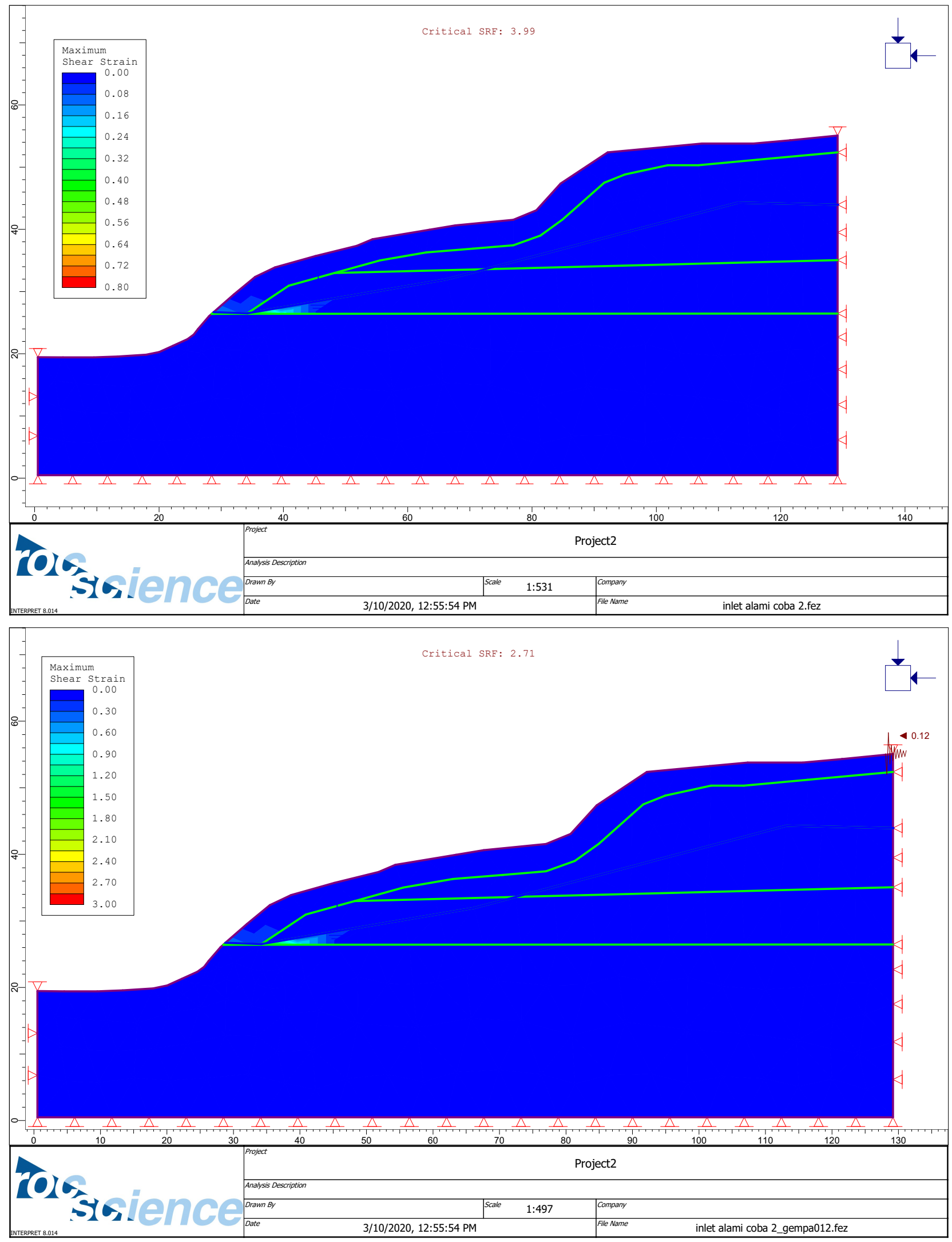

FIGURE 5. Contours of maximum shear strains developed in natural inlet slopes resulted from (a) static; (b) pseudostatic analyses. 

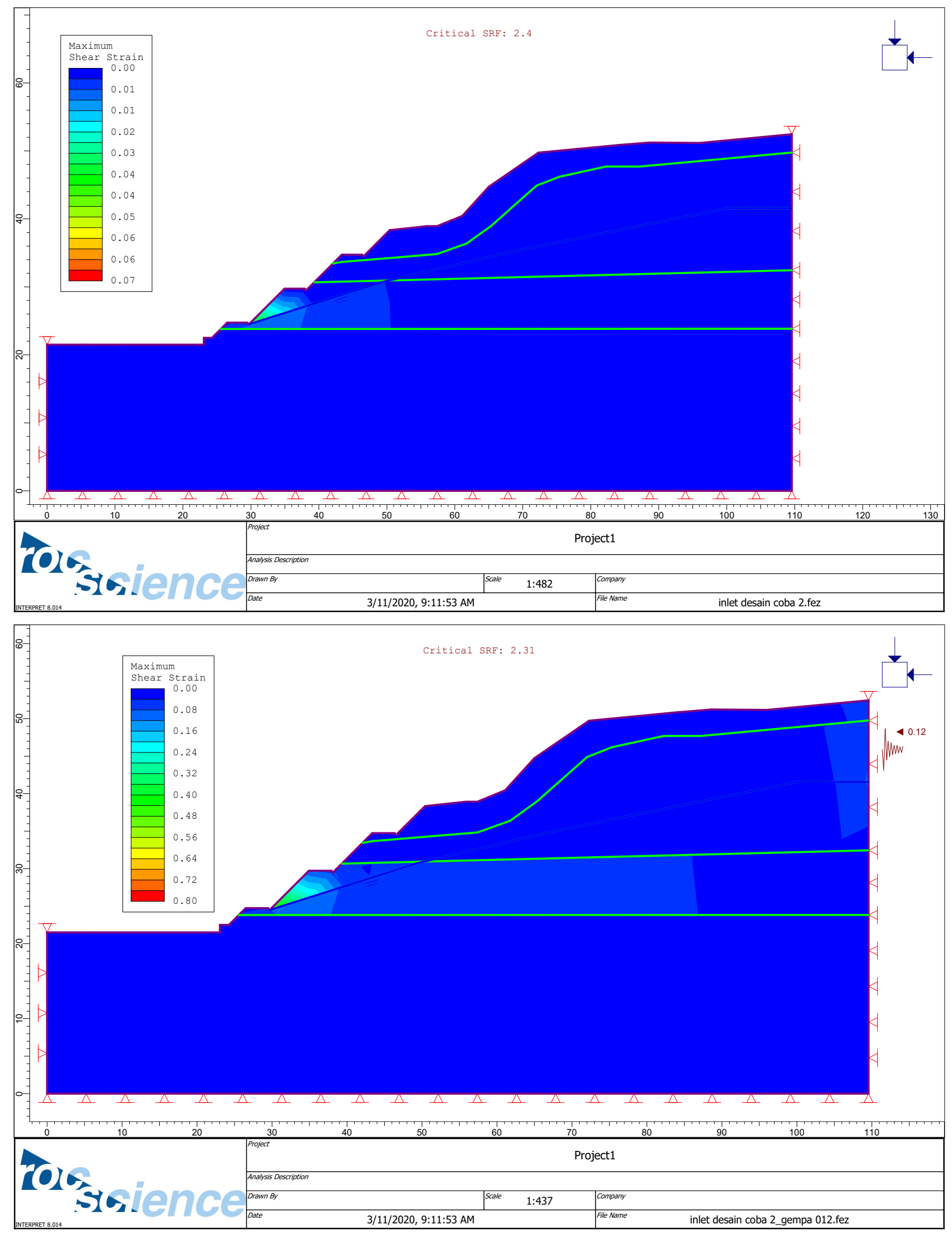

FIGURE 6. Contours of maximum shear strains developed in excavated inlet slopes resulted from (a) static; (b) pseudostatic analyses. 
Numerical Evaluation of Tunnel Portal Slope Stability at Bagong Dam Site
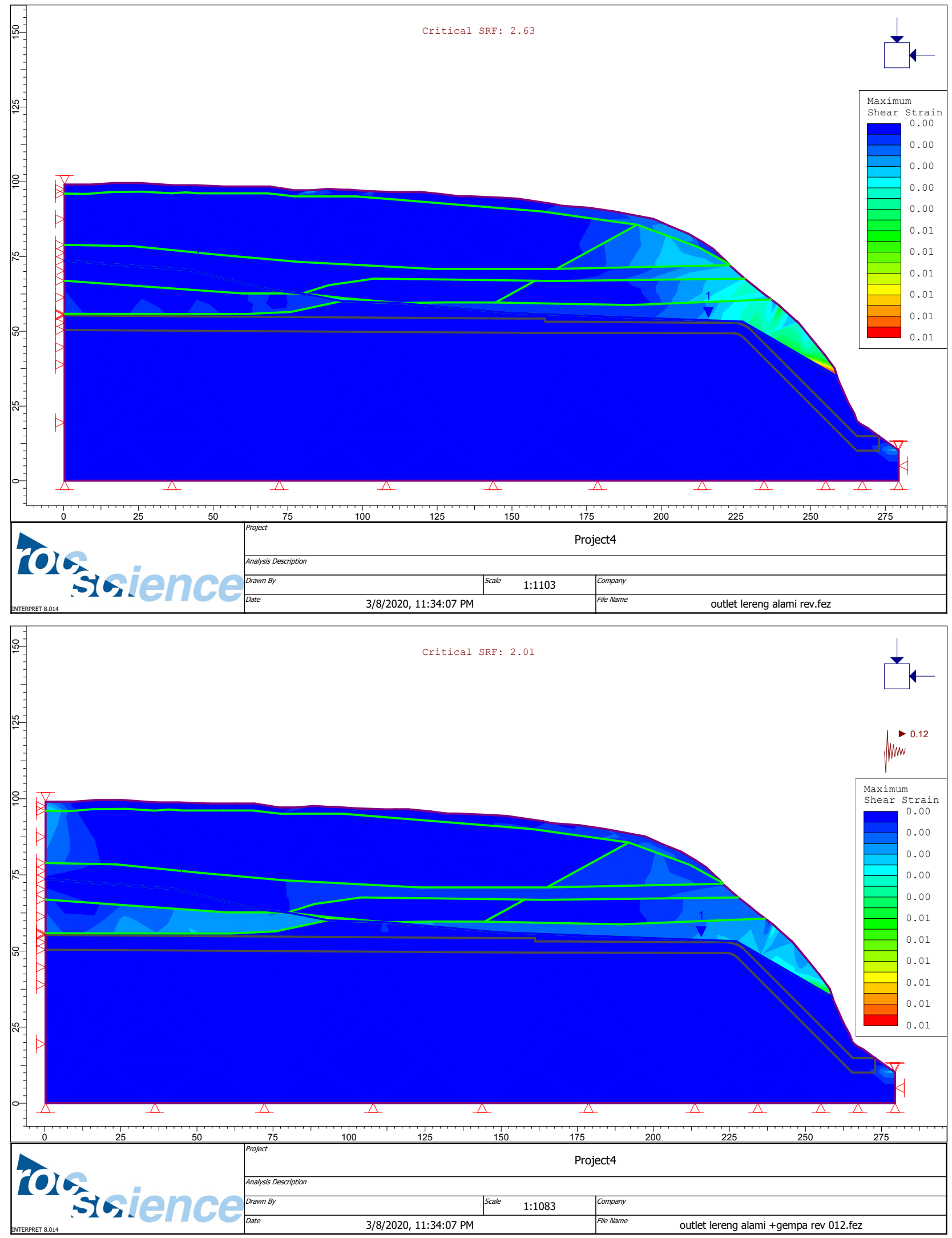

FIGURE 7. Contours of maximum shear strains developed in natural outlet slopes resulted from (a) static; (b) pseudostatic analyses. 
FATKHIANDARI et al.
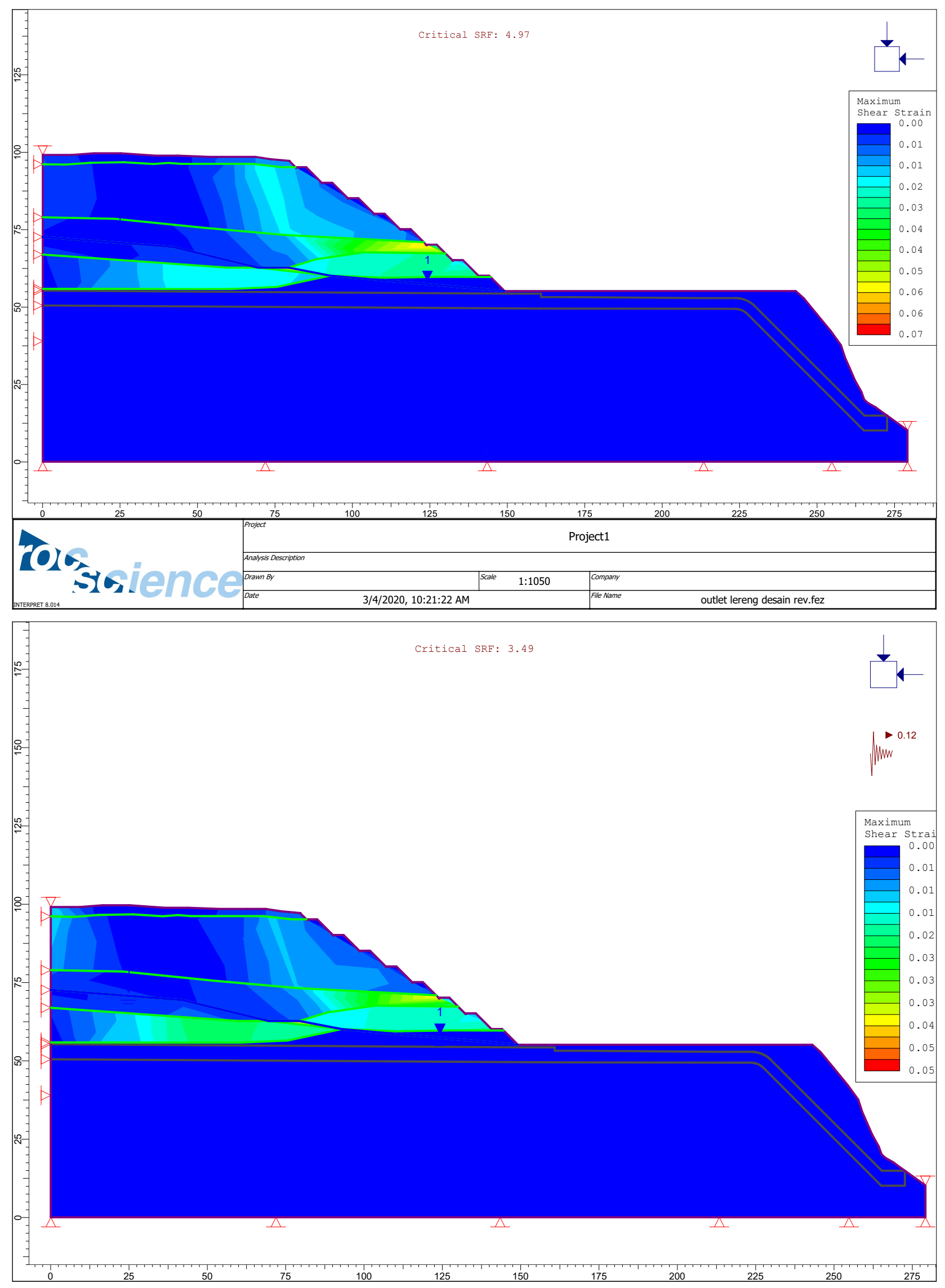

FIGURE 8. Contours of maximum shear strains developed in excavated outlet slopes resulted from (a) static; (b) pseudostatic analyses. 


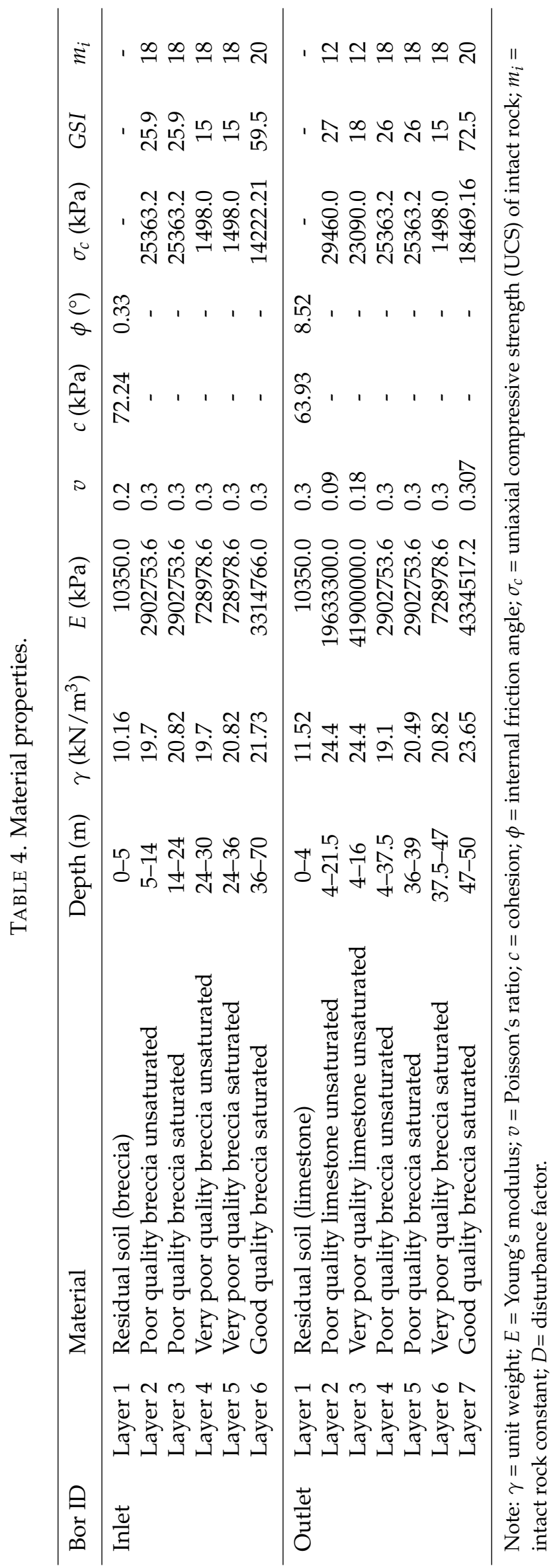

TABLE 5. Summary of slope stability analysis results.

\begin{tabular}{lcccc}
\hline \multirow{2}{*}{ Slope } & \multicolumn{4}{c}{ Critical SRF } \\
\cline { 2 - 5 } & \multicolumn{2}{c}{ Natural slope } & \multicolumn{2}{c}{ Excavated slope } \\
\hline $\begin{array}{c}\text { Static } \\
\text { load }\end{array}$ & $\begin{array}{c}\text { Earth- } \\
\text { quake } \\
\text { load }\end{array}$ & $\begin{array}{c}\text { Static } \\
\text { load }\end{array}$ & $\begin{array}{c}\text { Earth- } \\
\text { quake } \\
\text { load }\end{array}$ \\
\hline Inlet & 4.0 & 2.7 & 2.4 & 2.3 \\
Outlet & 2.6 & 2.0 & 5.0 & 3.5 \\
\hline
\end{tabular}

vided by the National Earthquake Center (2017) indicated that the PGA and the corresponding amplification factor FPGA in the research area were 0.3 and 0.8 , respectively. The calculated seismic coefficient for the pseudostatic slope stability analyses was 0.12 . The numerical analysis results showed that the earthquake load reduced the critical Strength Reduction Factor (SRF) values of the slopes. However, the natural and excavated tunnel portal slopes were relatively stable under static and earthquake loads. The natural slope at the tunnel inlet with a $40^{\circ}$ inclination had a critical SRF value of 4.0 , while that of at the tunnel outlet with a $51^{\circ}$ inclination had a critical SRF value of 2.6. Under static load, the excavated slopes at the tunnel inlet and outlet having a $45^{\circ}$ inclination had critical SRF values of 2.4 and 5.0, respectively. Under earthquake load, the excavated slopes at the tunnel inlet and outlet had critical SRF values of 2.3 and 3.5, respectively. In summary, the natural and excavated inlet and outlet portal slopes met the requirements specified in SNI 8460 (BSN, 2017) for seismic slope designs.

\section{ACKNOWLEDGEMENTS}

The authors would like to thank Balai Besar Wilayah Sungai (BBWS) Brantas, the Ministry of Public Works and Housing of Indonesia, for permission conducting this research. The first author would like to thank the Ministry of Public Works and Housing of Indonesia for the master's degree scholarship. The assistance of Ms. Elisabeth Cary Cesaria in conducting field and laboratory works is gratefully acknowledged.

\section{REFERENCES}

BBWS Brantas (2014) SID Bendungan Bagong 
Kabupaten Trenggalek termasuk Model Test. Surabaya.

BBWS Brantas (2017) Survey Investigasi Tambahan Geologi Bendungan Bagong di Kabupaten Trenggalek. Surabaya.

Bieniawski, Z.T. (1989) Engineering Rock Mass Classifications. John Wiley and Sons.

BSN (2017) SNI (Standar Nasional Indonesia) 8460: Persyaratan Perancangan Geoteknik. Jakarta.

Duncan, J.M., Wright, S.G., and Brandon, T.L. (2014) Soil Strength and Slope Stability. John Wiley \& Sons, Inc.

Fatkhiandari, I.A. (2020) Analisis Kestabilan dan Sistem Penyangga Terowongan Saluran Pengelak Bendungan Bagong Kabupaten Trenggalek Provinsi Jawa Timur. Master Thesis. Departement of Geological Engineering Universitas Gadjah Mada. Unpublished.

Griffith, D. V. and P. A. Lane (1999) Slope Stability Analysis by Finite Elements. Geotechnique 49, No. 3., p 387-403

Hartono, U., Baharuddin, dan Brata, K. (1992) Peta geologi regional lembar Madiun. Pusat Penelitian dan Pengembangan Geologi.
Hammah, R.E, Curran, J.H., Yacoub, T., and Corkum, B. (2004) Stability Analysis of Rock Slopes using the Finite Element Method. In: EUROCK 2004 \& 53 ${ }^{\text {rd }}$ Geomechanics Colloquium, Schubert (ed.).

Hoek, E., Carter, T.G., Diederichs, M.S. (2013) Quantification of the Geological Strength Index Chart. Geomechanics Symposium, USA.

National Earthquake Research Centre (2017) Peta Sumber Bahaya dan Gempa Indonesia, Jakarta. Kementerian Pekerjaan Umum dan Perumahan Rakyat.

Pulunggono, A. dan Martodjojo, S. (1994) Perubahan Tektonik Paleogen-Neogen di Jawa. In: Proc. Seminar Geologi dan Geotektonik Pulau Jawa. Yogyakarta. Geological Engineering Department Gadjah Mada University.

Rocscience Inc. (2001) Application of the finite element method to slope stability, Toronto, 20012004. URL: https:/ / www.rocscience.com/assets / resources/learning/papers/Application-of-theFinite-Element-Method-to-Slope-Stability.pdf

Wyllie, D.C. (2018) Rock Slope Engineering-Civil Applications. Taylor \& Francis Group, LLC. 